Primljeno 26. 6. 2019, prihvaćeno za objavljivanje 29. 8. 2019.

\section{Edina Rizvić-Eminović, PhD}

Faculty of Philosophy, University of Zenica edina.rizvic@gmail.com

\section{Đelaludina Šukalić, MA}

Faculty of Philosophy, University of Zenica djelasukalic@hotmail.com

\title{
CORPUS-BASED STUDY OF THE MODAL VERBS IN THE SPOKEN AND ACADEMIC GENRES OF THE CORPUS OF CONTEMPORARY AMERICAN ENGLISH
}

\begin{abstract}
This corpus-based study focuses on the nine English central modal verbs (can, could, will, would, may, might, shall, should, and must) across the two chosen genres of the COCA corpus - Spoken and Academic genres, which show the greatest number of differences in terms of genre characteristics, such as formality or intended audience. Because research on modal verbs across genres, especially one inclusive of the spoken genre, is limited, this study investigates these two genres to test the hypothesis that the general genre characteristics influence the choice of modal verbs. As a result, the distribution of modal verbs across the different genres differs too. The results suggest that genre can indeed be indicative of the frequency and use of modal verbs, which may be ascribed to two language processes colloquialization and democratization.
\end{abstract}

Keywords: modal verbs, spoken, written, genre, distribution.

\section{Introduction}

The present study developed out of the need for a comprehensive and detailed research which would include multiple modal verbs across different genres, especially the spoken variety (Bowie, Wallis, \& Aarts, 2013; Coates \& Leech, 1980). The purpose of the paper is to investigate two genres of the Corpus of Contemporary American English with the greatest number of 
differences, the Academic and the Spoken genre, in order to test the hypothesis related to the distribution of nine central modal verbs across those genres. Because of the noted influences of the text types on the frequency of use of modal verbs (Mindt, 1995), the following hypothesis was investigated in the paper: Academic genre shows different distribution and frequency of use of the nine central modal verbs compared to the spoken genre. The Spoken genre, characterized as a genre intended for general audience, informal in nature, mainly focusing on general vocabulary, and more open to change, greatly differs from the Academic genre intended for specialized audience, formal in nature, inclusive of technical and professional jargon and more closed to change (Biber $\&$ Conrad, 2009). Furthermore, the authors' preliminary research results indicate that the most striking differences in terms of the distribution of central modal verbs can be found between these two genres. Therefore, according to the hypothesis, the difference in the frequency and distribution of central modal verbs may be ascribed to the different characteristics of the two genres.

The research area of modal verbs across genres has yet to be fully explored. One of the early research studies on modal verbs with any respect to genre or stylistic differences, the corpus informed study by Coates and Leech (1980), indicated the need for further research, especially one inclusive of spoken genre (Coates $\&$ Leech, 1980). This paper was followed by Coates' (1983) study on The Semantics of the Modal Auxiliaries, one of the most important corpus-based works on modal verbs according to modality types which focused on the meaning of modal verbs in both spoken and written British English. The need for further research, one inclusive of the spoken English, was also brought up by Bowie, Wallis, and Aarts (2013), who state that previous studies have rarely focused on the influence of the text types and even then, they were limited to the domain of the written English. Another important study on modal verbs which provides more information on specific genre differences is The Longman Grammar of Spoken and Written English (Biber, Johansson, Leech, Conrad, \& Finegan, 1999). This work includes noted differences across four genres of the LSWE corpus (fiction, news, academic and conversation). The authors (Biber et al., 1999) suggest that modals and semi-modals are most common in conversation and 
that the frequency of modal verbs according to genres varies so, for example, may is rare in conversation compared to will, which is extremely common in conversation and news reportage (Biber et al., 1999, pp. 487-488). Some recent research in this direction, such as Millar's (2009) analysis of modal verbs in TIME magazine, still remains at the level of either a specific genre or a case study.

The two genres of interest, spoken and academic, were chosen because of their main characteristics which differ in several key ways. While spoken genre has been the subject of numerous studies across different disciplines and from various standpoints (including critical discourse analysis, applied linguistics and English for Specific Purposes), when it comes to studies which would focus on modal verbs, the existing research has been quite limited. Spoken genre can also prove of interest for the analysis of modal verb use as one of its main characteristics is that "speakers in the conversation make frequent reference to themselves (I, we), describing their own personal thoughts, feelings, past and present activities" (Biber et al., 1999, p. 11). Therefore, this genre can be of particular interest in the area of epistemic modality, in terms of prediction and lack of speaker's knowledge, and in the area of dynamic modality, in terms of volition and intention. One of the reasons for the noted lack of research on spoken genre, from the linguistic standpoint, might be the question of availability, meaning that obtaining data is much more complex and there are many variables in the process of capturing and transcribing the spoken data (Biber et al., 1999). Academic genre has been the most researched variety when it comes to the written form (O'Keeffe \& McCarthy, 2004) and modality within the academic writing has been addressed as well (Hinkel, 2009). The academic writing can be described as "a very general register, characterized as written language that has been carefully produced and edited, addressed to a large number of readers who are separated in time and space from the author, and with the primary communicative purpose of presenting information about some topic" (Biber \& Conrad, 2009, p. 32). In other words, it is a formal, written genre intended for a specialist audience. As a result, even though it shares some characteristics with other written genres, the main difference is its predominantly communicative purpose and the degree of formality. 
Modality is discussed in terms of the tripartite distinction between epistemic, dynamic, and deontic modality types. Epistemic modality entails that "the speaker uses inference or evidence from his existing knowledge to try and establish or assess the potential factuality of propositions" (Salkie, Busuttil, \& Auwera, 2009, p. 55). In other words, the speaker makes predictions about the possibility and probability of proposition expressed by the speech act. On the other hand, deontic modality entails direct speaker's involvement as "the speaker uses his volition, his authority or his reason to seek to bring about the occurrence (or non-occurrence) of potential situations (events, acts, processes, states, etc.)" (Salkie et al., 2009, p. 55). Therefore, deontic modality refers to the ideas of obligation and permission and it is used to issue a command, give permission, make a promise or make a wish or a threat. The final type of modality, dynamic modality, is internal to the subject of the sentence and it refers to the need, ability or disposition of the speaker.

The research results are discussed in terms of the two language processes, democratization and colloquialization. Democratization proposes that people avoid using face threatening speech acts and strong deontic modal verbs such as must which gives way to the increased use of other, weaker deontic modal verbs. For example, the decline of must and the increase of should might be the results of the democratization as such developments represent "a tendency to suppress or avoid overt claims to power and authority by the speaker or writer" (Leech, 2003, p. 237). In fact, modal verbs with such deontic readings can be interpreted as one of many linguistic forms used to reduce the illocutionary force of speech acts (Facchinetti, 2003). The second language process of interest is the colloquialization process, which can be described as a stylistic shift from an established written, formal use to the more informal varieties typical of spoken usage (Mair, 2006).

\section{Methodology}

The focus of the present study were the nine central modal verbs within the two chosen genres of the Corpus of Contemporary American English. As the investigation into the text varieties has to be "comparative, quantitative and based on a representative 
sample" (Biber \& Conrad, 2009, p. 51) the COCA represents a great resource for the frequency and distribution analysis. The Corpus of Contemporary American English (COCA), compiled by Mark Davies of Brigham Young University, contains more than 560 million words and it is divided into five genres: spoken, fiction, popular magazines, newspapers, and academic texts. When it comes to individual genres, with COCA, "perhaps more easily than with any other corpus architecture" (Davies, 2009, p. 185), it is possible for users to make frequency comparisons across genres as well as to search for "the frequency of each individual type in each of the five major genres" (Davies, 2009, p. 186).

The first step in the process of frequency analysis for this research was to run a query in the form of _vm* from the search box while choosing Lemma within Options and setting the Display section to 'per million' as this query resulted in both raw and normalized frequency. The second step was to search for all modal verbs within the two chosen genres, which was done by using the same query but choosing the specific options within sections, that is, the wanted genre and the Chart option. Thus, it was possible to calculate percentages for the two genres with respect to the total frequency of modal verbs within a genre as well as the individual frequency of the nine central modal verbs. The frequency percentages were determined for all nine modal verbs and the data was presented in figures indicating the distribution and frequency of modal verbs across the two chosen genres, as well as the three other genres of COCA: Fiction, Newspaper, Magazines. Their frequency figures were included to confirm that the most striking differences can be found between the Spoken and Academic genres. Additional figures focusing on the frequency of modal verbs within the subsections of the Academic genre were also created in order to gain insight into the influence of text types typical of this genre. The subsections within this genre include the following: Education, History, Geography/Social Science, Law/Political Science, Humanities, Philosophy/Religion, Science/Technology, Medicine, and Miscellaneous.

The analysis did not focus only on the quantitative investigation of the differences but also on the possible reasons behind the observed results. The impact of genre in combination with the theoretical framework of colloquialization and 
democratization (Leech, 2003) was a point of interest as well. For example, the deontic meaning of the modal verb must was discussed with respect to the democratization process and such conclusions were additionally corroborated by the influence of the spoken genre on the lower frequency of the deontic must.

\section{Results and Discussion}

Investigation into frequency and distribution of modal verbs across genres of COCA, as presented in Figure 1, suggests that central modal verbs are most frequent in the Spoken genre (24.31\%), followed by Fiction (22.65\%), Magazine (19.25\%), Newspaper (17.62\%), and, finally, Academic genre (16.17\%).

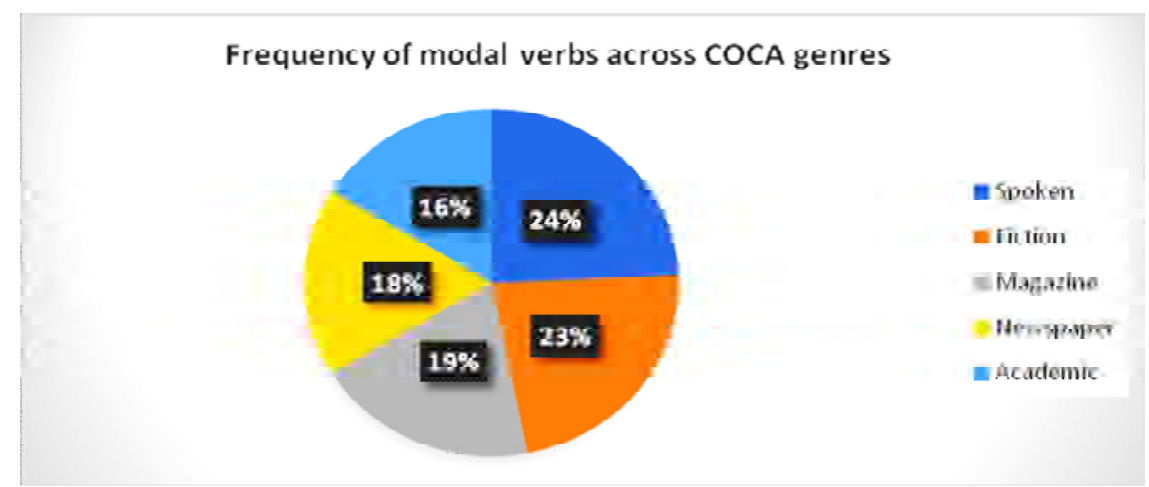

Figure 1. Frequency of modal verbs across COCA genres.

The most noticeable differences are found between the two most different genres in terms of genre characteristics - Spoken $(24.31 \%)$ and Academic (16.17\%) genre, which supports the necessity of comparative research across these genres. The highest frequency of modal verbs in the Spoken genre can be explained by the fact that modal verbs tend to indicate "stance-type meaning" (Biber et al., 1999, p. 487) so the Spoken genre is the natural leader in this sense. Furthermore, other corpus-based studies have also indicated high frequency of modal verbs in the spoken genre (Biber et al., 1999; Leech, Hundt, Mair, \& Smith, 2009; Biber \& Conrad, 2009). However, sometimes, the results also indicate the highest decrease within the same genre which works towards bridging the gap between spoken and written varieties (Leech, Hundt, Mair \& 
Smith, 2009). One of the explanations for such results is offered in the form of potential modals - semi-modals transposition, that is, it is implied that semi-modals seem to be replacing modals (Biber, Conrad \& Reppen, 1998; Krug, 2000; Leech et al., 2009). More formal, specialist, written genres, such as the Academic genre, contain lower frequency of modal verbs with tendency of decrease over time compared to more informal, spoken genre, which seems to resist the change much better, even though certain uses, such as obligation are limited in the Spoken genre. To offer further evidence for this claim, the focus will now be on the analysis of the nine central modal verbs themselves. The nine central modal verbs within COCA show interesting differences when it comes to their raw and normalized frequency count. The list of modal verbs according to their frequency count and percentages is presented in Figure 2.

\section{Total raw and normalized frequency of modal verbs}

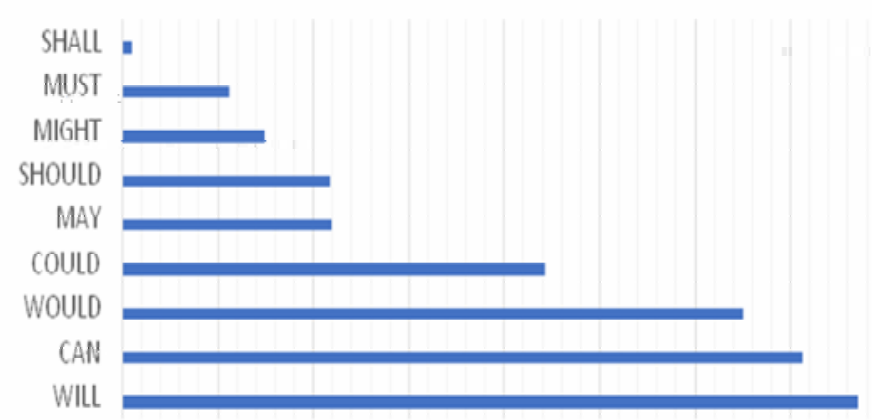

$0 \quad 200000 \cdot 400000 \quad 60000080000010000001200000140000016000001800000$

\begin{tabular}{|l|c|c|c|c|c|c|c|c|c|}
\hline & WILL & CAN & WOULD & COULD & MAY & SHOULD & MIGHT & MUST & SHALL \\
\hline a Per Mil & $23,46 \%$ & $21,70 \%$ & $19,81 \%$ & $13,49 \%$ & $6,65 \%$ & $6,64 \%$ & $4,54 \%$ & $3,39 \%$ & $0,32 \%$ \\
\hline aRaw frequency & 1540838 & 1425517 & 1301223 & 885761 & 436785 & 435875 & 298118 & 222810 & 20965 \\
\hline
\end{tabular}

\section{- Per Mil @aw frequency}

Figure 2. Total raw and normalized frequency of modal verbs.

The results show that the frequencies of specific modal verbs differ greatly. For example, modal verb shall makes up only $0.32 \%$ of the total frequency of modal verbs with only 20.965 examples in 
total. After determining that the total and individual frequencies of modal verbs across genres differ, the next step was to investigate whether the most and the least frequent modal verbs in total are also the most and the least frequent modals across genres as well. Figure 3 contains the normalized frequency of all nine central modal verbs across the two genres analysed.

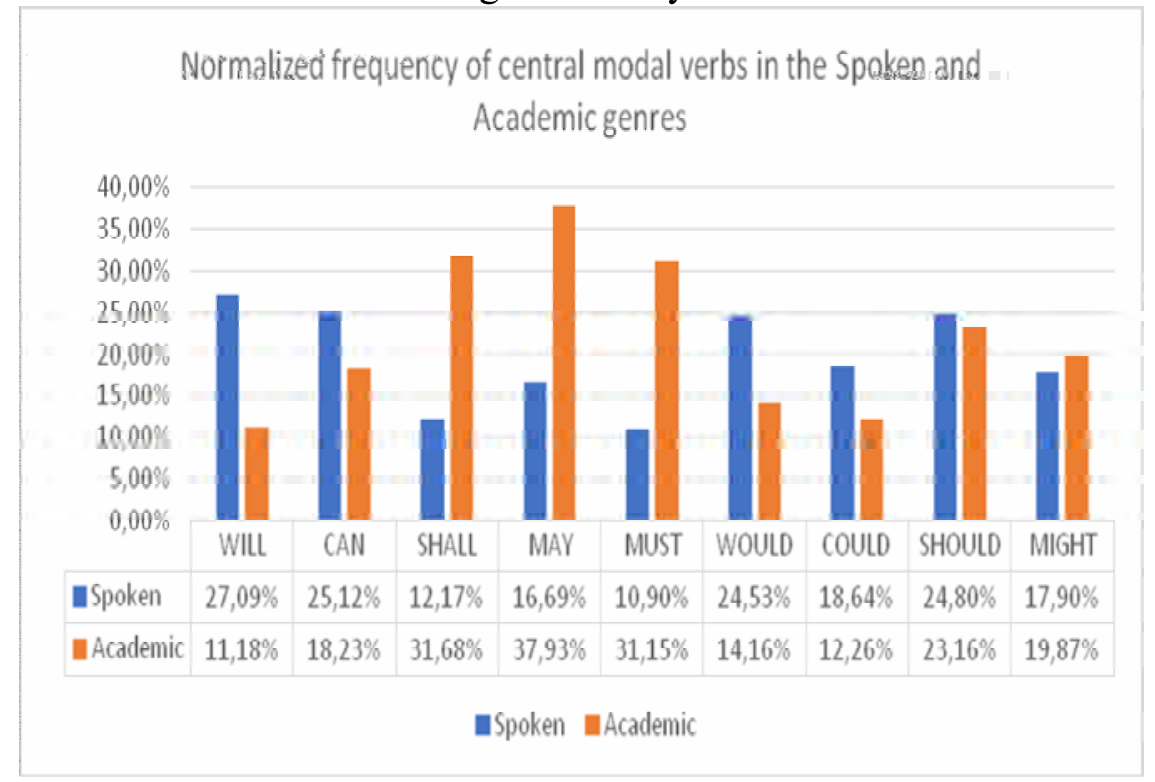

Figure 3. Normalized frequency of central modal verbs in the Spoken and Academic genres.

The results suggest that modal verbs show different patterns of distribution across genres. As with total frequency, we can notice clear differences between the spoken, informal, and written, formal genre. For example, Spoken genre, containing the highest total frequency of modal verbs, shows the lowest frequency count (out of all five genres) for the modal verb must (10.90\%) as well as lower percentages for the modal verbs shall $(12.17 \%)$ and may $(16.69 \%)$. On the other hand, the more formal, written Academic genre shows the opposite figures, containing the highest frequency of both must (31.15\%) and may (37.93\%), as well as a high frequency of the modal verb shall $(31.68 \%)$. Furthermore, as the Spoken genre also contains a high frequency of the modal verb should $(24.80 \%)$, it seems likely that such a distribution is the 
result of the democratization process as less face threatening options are used within the Spoken genre. This consequently suggests that genre can, indeed, indicate the distribution and modality types of modal verbs. In an attempt to describe and explain the observed differences and the reasons behind them, an analysis of each of the nine central modal verbs and the differences across the two chosen genres was performed.

\section{Would}

Modal verb would makes up $19.81 \%$ of the total frequency of the modal verbs in COCA and, as Figure 4 indicates, is most frequently used in Fiction (27.17\%) and Spoken (24.53\%) genre. On the other hand, it is the least used in the Academic genre.

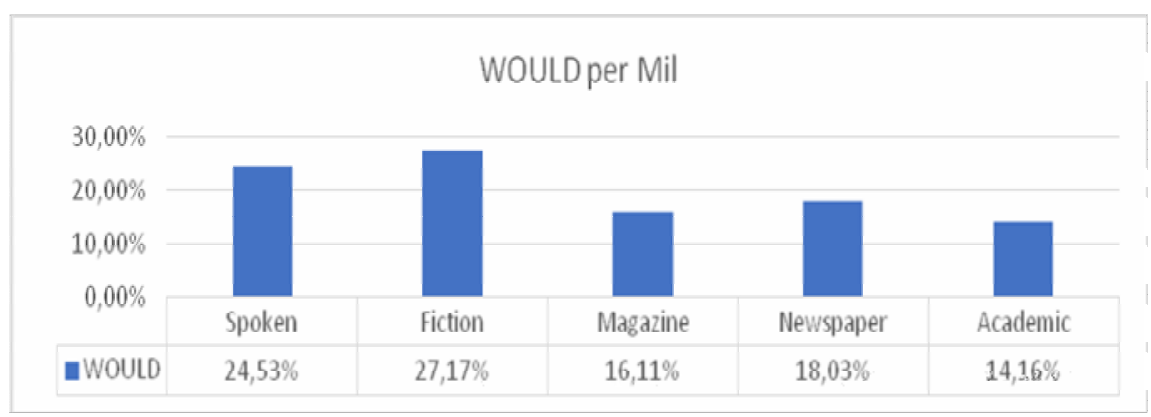

Figure 4. Normalized frequency of WOULD across genres.

These results are interesting as formal subsections, allowing for a more personal approach expressing stance, favour the use of would.

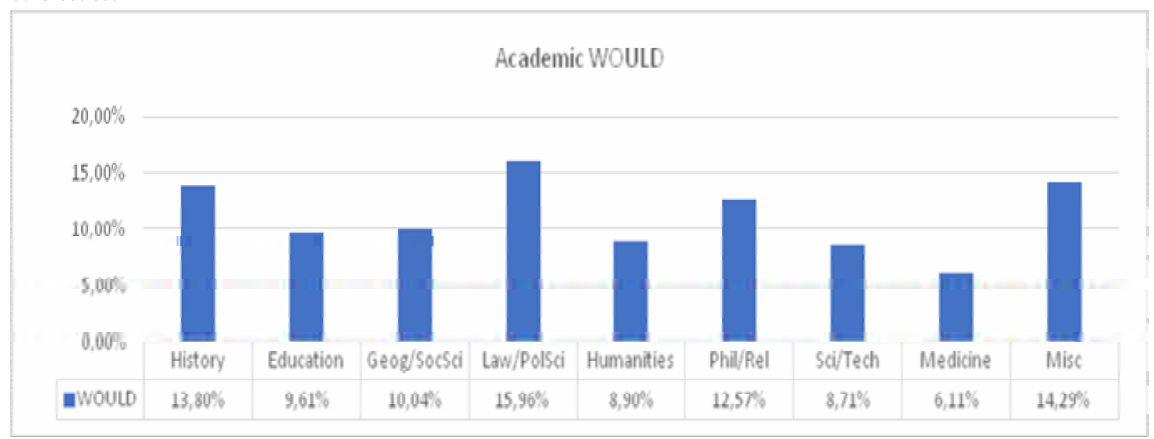

Figure 5. Frequency of WOULD across subsections of the Academic genre. 
Further investigation into subsections within the Academic genre confirms this and Figure 5 leads to the conclusion that the lowest frequency numbers are found in the mainly scientific subsections such as Medicine (6.11\%) and Sci/Tech $(8.71 \%)$ compared to the social science subsections such as Law/PolSci $(15.96 \%)$.

\section{Can}

Modal verb can is the second most frequent verb in COCA taking up $21.70 \%$ of the overall frequency of modal verbs. Figure 6 indicates that it is most frequently found in the Spoken genre $(25.12 \%)$ and it is closely followed by the Magazine genre (23.64\%).

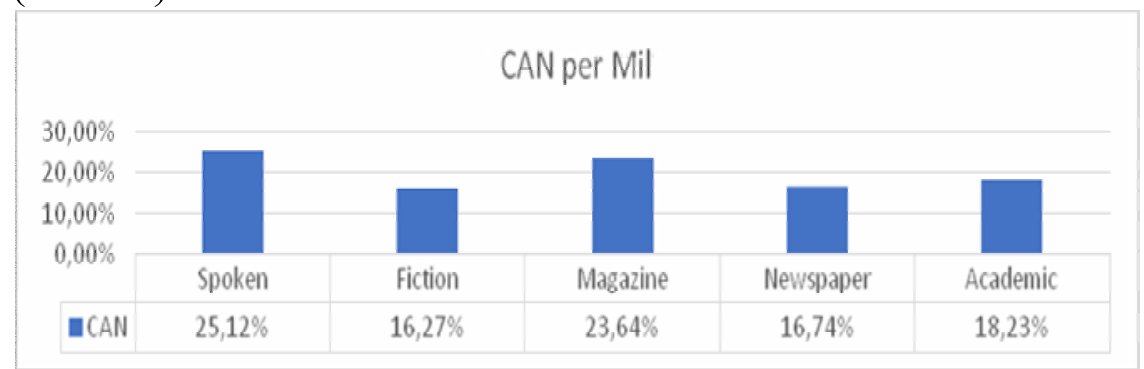

Figure 6. Normalized frequency of CAN across genres.

On the other hand, its frequency is noticeably lower in the Academic (18.23\%) and Newspaper (16.74\%) genres followed by Fiction, which contains the lowest frequency (16.27\%). The third place, according to frequency, is reserved for the Academic genre, which is very important as it has been determined that this genre contains the lowest overall frequency of the modal verbs and has the most tendencies for decrease. The possible explanation might be related to the modality types and particular meanings of this verb as can may be used to indicate both the possibility and the ability meanings and both are employed in the Academic genre. In other words, very often, certain examples for the modal verb can, offer for ambiguous reading between epistemic and dynamic meaning, that is, the speaker's pure assumption or dynamic possibility, respectively. Therefore, even though both would and can favour informal genres, because of the meaning and modality 
types of can, can shows higher presence within the Academic and more formal genres as well.

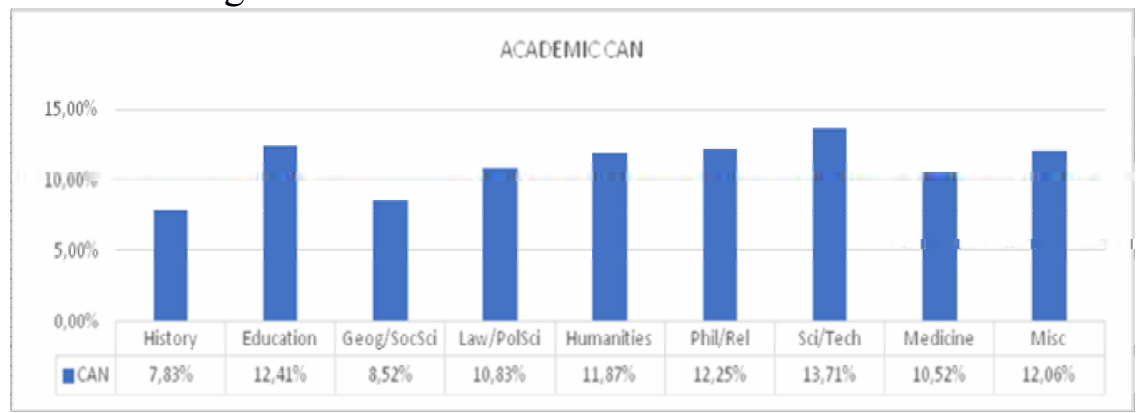

Figure 7. Frequency of the modal verb CAN across the subsections of the Academic genre.

Another evidence in favour of this claim is presented in Figure 7, where the two subsections allowing for the least amount of epistemic meanings to be employed (History and Geog/SocSci) show the lowest frequency compared to the Sci/Tech and Education subsections favouring greatly the dynamic meanings of can as these genres most often deal with the ability/capability meanings.

\section{Will}

Modal verb will shows the highest frequency out of all the modal verbs, taking up $23.46 \%$ of the total modal verb count. The results in Figure 8 show that the highest frequency of will is reserved for the Spoken genre $(27.09 \%)$ followed by Newspaper $(22.74 \%)$ and Magazine (20.48\%). Fiction genre (18.50\%) is on the lower end of the scale while the lowest frequency can be observed in the Academic genre with only $11.18 \%$. Once again, the most notable differences are seen between the two chosen genres.

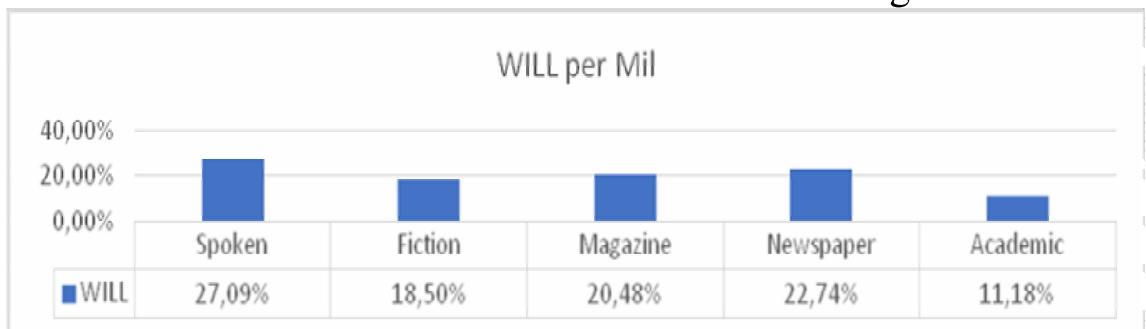

Figure 8. Normalized frequency of WILL across genres. 
It is interesting to make comparisons between will and would as will is more present in the Spoken (27.09\%) over Fiction genre $(18.50 \%)$, while with would the opposite is true. Additionally, will has even lower frequency in the Academic genre (11.18\%). These differences could be the result of colloquialization as will with its won't form might have caused higher frequency numbers in the Spoken genre compared to written, formal Fiction and Academic genres. Once again, Academic genre differs the most compared to others when it comes to modal verb use.

Figure 9 establishes that the lowest frequency can be found in the Geo/SocS (7.32\%) and Medicine (8.02\%) subsections while the highest is found in the Law/PolSci (15.68\%) and Sci/Tech (13.54\%) subsections. The prediction aspect of the epistemic meanings of will and the lack of strong hedging traits might be the reason behind such results.

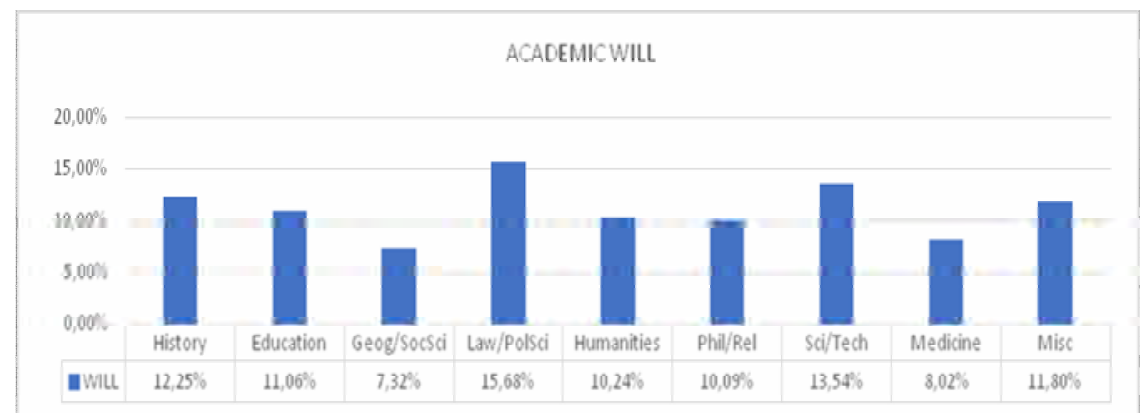

Figure 9. Frequency of WILL across the subsections of the Academic genre.

\section{Could}

Modal verb could makes up $13.49 \%$ of the total count of the modal verbs in the COCA. Could shows the highest frequency in the Fiction genre $(36.16 \%)$ with the other four genres containing much lower numbers. According to the results presented in Figure 10, Fiction is followed by the Spoken (18.64\%), Magazine $(16.72 \%)$, Newspaper (16.21\%) and finally, Academic genre $(12.26 \%)$. 


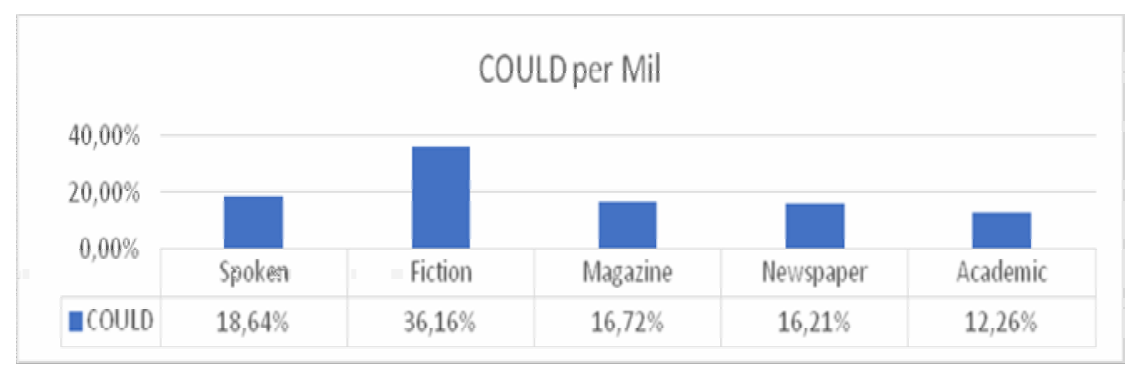

Figure 10. Normalized frequency of COULD across genres.

It is possible to make comparisons with would, which shows similar results in terms of Fiction, containing the highest, and Academic genre the lowest frequency numbers. The prevalence of could/would in Fiction genre compared to can/will could be a result of colloquialization as can/will are more present in the Spoken, more informal genre and the more tentative, polite forms could/would are more present in the Fiction genre. Once again, this seems to suggest a clear connection between genre and modal verbs in use.

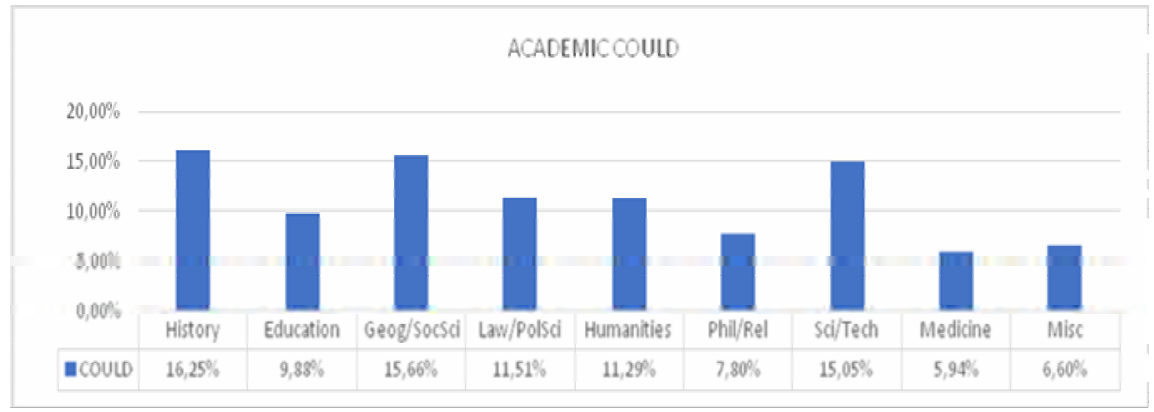

Figure 11. Frequency of COULD across subsections of the Academic genre.

As presented in Figure 11, the lowest frequency in the Academic genre is found in the Medicine subsection (5.94\%), while the highest is seen in the History (16.25\%) subsection. Hedging is often employed in medical texts and many other modal verbs provide better choices to express such meanings, which could potentially explain the low frequency numbers. On the other hand, History subsections obviously benefits from the past form of this particular modal verbs across all of its meanings. 


\section{May}

Modal verb may with the frequency of only $6.65 \%$ is also on the lower end of the total frequency scale of modal verbs in the COCA. It is interesting to note that the verb losing its frequency steadily over the years is, in fact, the verb most frequently used in the Academic genre (37.93\%). With other verbs, Academic genre has consistently shown very low frequency numbers and this genre, where modal verbs are most consistently on the decrease (Bowie et al., 2013), shows the highest numbers for may (37.93\%). This seems to support the bottom weighting theory that the lowest frequency members are the most certain to suffer further decrease. It also makes it interesting to investigate the modality types with respect to may, as potential hedging qualities of may (Hyland, 1998) can be the reason for its frequent use in the Academic genre. Academic genre is followed by Magazine (24.22\%), Spoken $(16.68 \%)$ and Newspaper (15.26\%) genres while the lowest frequency numbers are in the Fiction genre, with the frequency of only 5.91\%, as indicated in Figure 12.

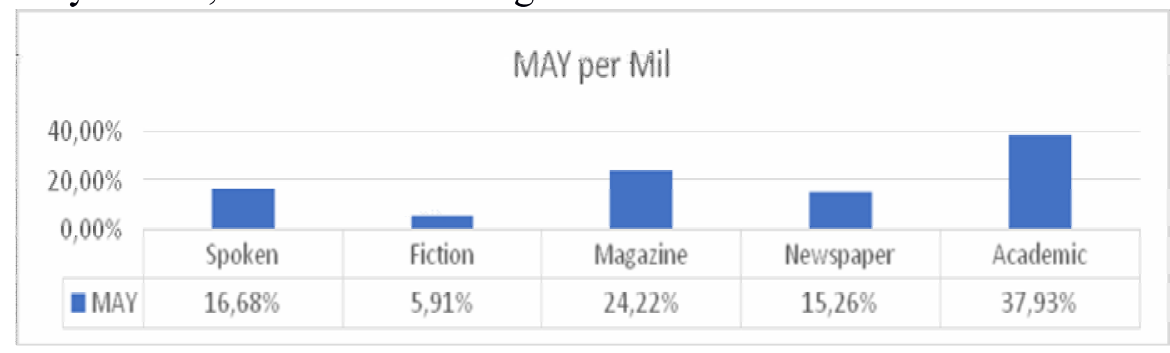

Figure 12. Normalized frequency of MAY across genres.

Figure 13 indicates that the lowest frequency can be found in the History subsection (7.00\%), once again because of the nature of the text type which favours might. On the other hand, apart from the Misc subsection, which includes various text types and, as such, favours epistemic, hedging qualities of may, high frequency is also noted in the Phil/Rel subsection and an interesting avenue for further research could be investigation into modality types of may within this subsection, as it also strongly favours the deontic meaning of this particular modal verb. 


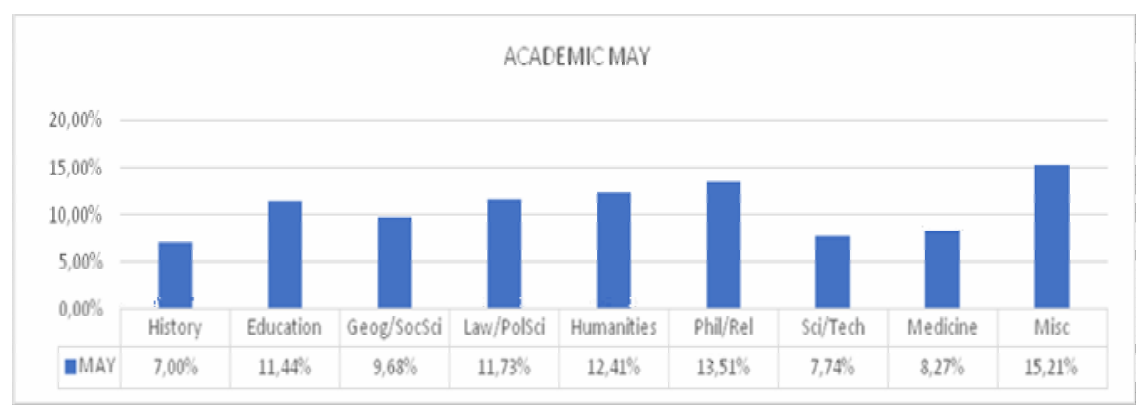

Figure 13. Frequency of MAY across subsections of the Academic genre.

\section{Should}

Should is represented by only $6.64 \%$ of the modal verb frequency in COCA. Modal verb should is extremely interesting, as it shows the highest frequency in the Spoken genre $(24.80 \%)$, followed by the Academic genre $(23.16 \%)$, as indicated in Figure 14.

Usually, as these two genres are almost the complete opposite, they also show the opposite results as seen from the previous modal verb, however, with should that is not the case. The potential explanation could be in the democratization of should, which is being used in the Spoken genre as a less face threatening option in terms of weak obligation meaning when compared to must. Furthermore, with its meaning of weak obligation and necessity, its use in the more formal, specialist, Academic genre is to be expected.

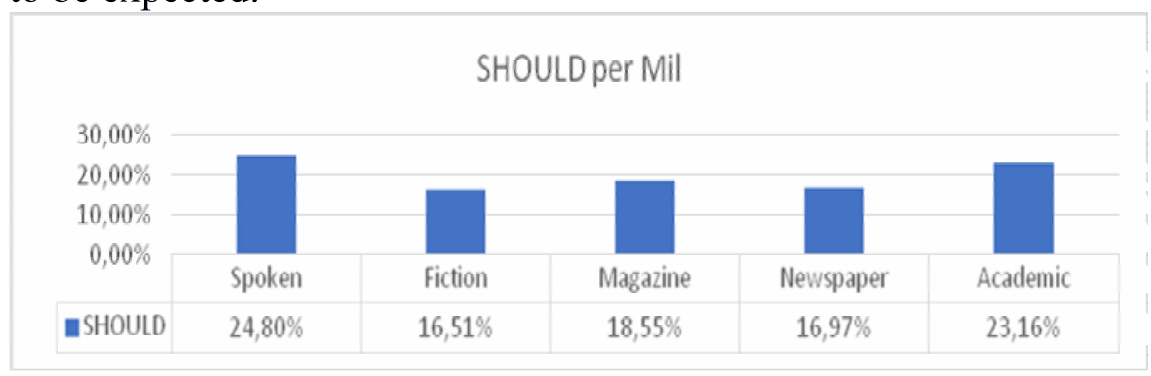

Figure 14. Normalized frequency of SHOULD across genres. 


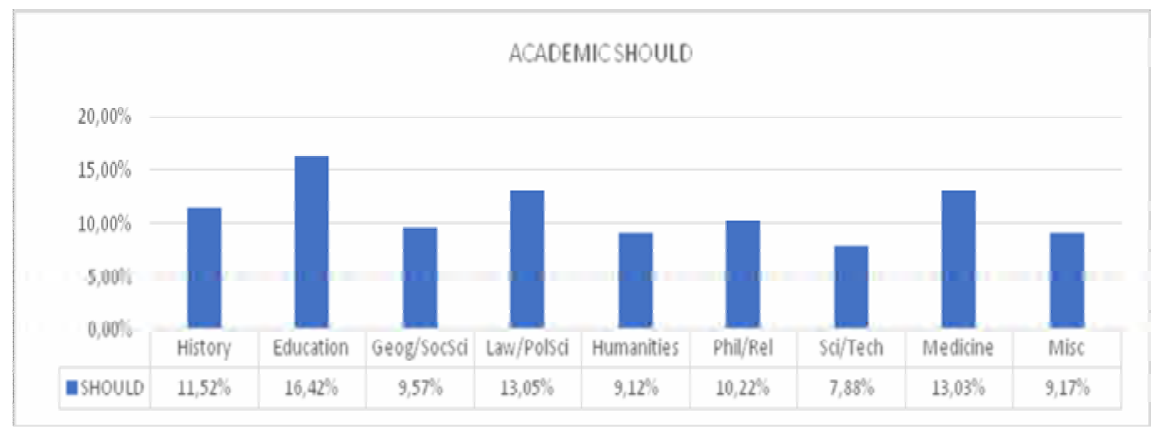

Figure 15. Frequency of SHOULD across subsections of the Academic genre.

As presented by Figure 15, the highest frequency within the Academic genre is in the Education (16.42\%), Law/PolSci $(13.05 \%)$ and Health (13.03\%) subsections while the lowest is in the SciTech (7.88\%) subsection. Once again, modality types could be responsible, as weak obligation favours didactic texts and hedging is standard in medical writing.

\section{Might}

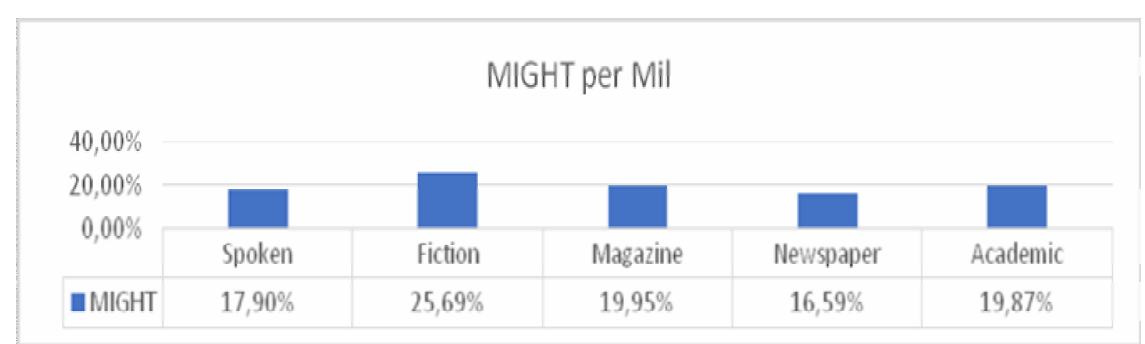

Figure 16. Normalized frequency of MIGHT across genres.

Might shows the highest frequency in the Fiction genre (25.69\%) and, as Figure 16 indicates, Fiction genre is followed by Magazine (19.95\%) and Academic (19.87\%) genres, which have almost the identical numbers. Spoken and Newspaper genres contain somewhat lower frequency with $17.90 \%$ and $16.59 \%$, respectively. 


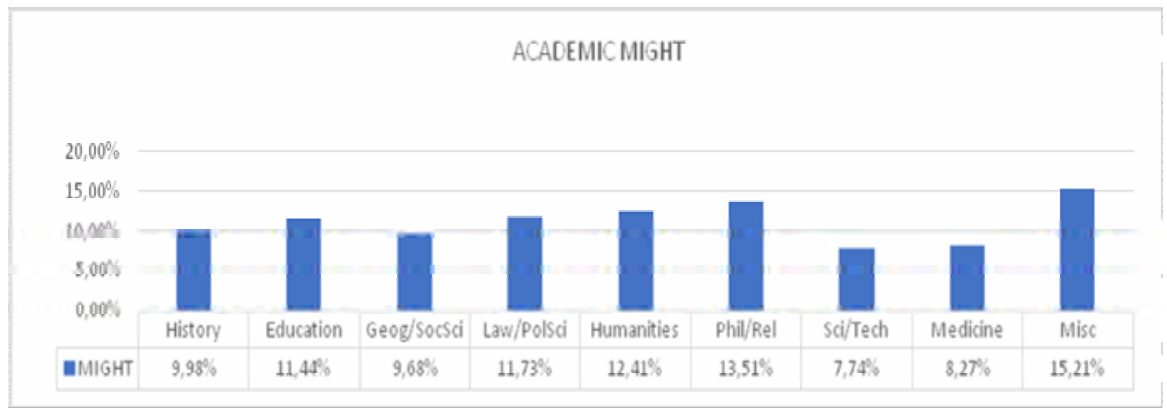

Figure 17. Frequency of MIGHT across the subsections of the Academic genre.

The results of the subsections of Academic genre, as presented by Figure 17, show high frequency numbers in Misc, Phil/Rel and Humanities subsections and low frequency in Medicine section with the lowest frequency reserved for the Sci/Tech subsection of the Academic genre (7.74\%). The low frequency counts correspond to the results for the modal verb would. This could be a further evidence of the genre distinctions, as despite the text types and similarities, the overall characteristics of a genre seem to have the most important influence over the final results.

\section{Must}

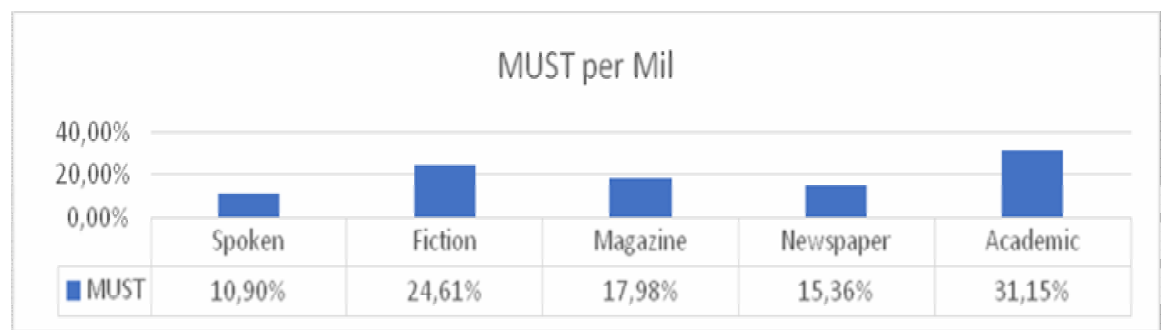

Figure 18. Normalized frequency of MUST across genres.

As Figure 18 shows, Academic genre contains the highest frequency of modal verb must $(31.15 \%)$, which is not unusual for a formal, written, specialist genre. On the other hand, the informal, Spoken genre shows the lowest frequency by far $(10.90 \%)$. 
Academic genre is followed by Fiction (24.61\%), Magazine $(17.98 \%)$ and finally Newspaper $(15.36 \%)$ genres.

Figure 19 illustrates that within the Academic genre Phil/Rel, Education, Law/PolSci show the highest frequencies as opposed to $\mathrm{Geog} / \mathrm{SocSci}$ and Medicine subsections. Once again, modality types could be the reason behind such results as deontic obligation meaning is more appropriate for religious and educational texts compared to medical texts favouring hedging.

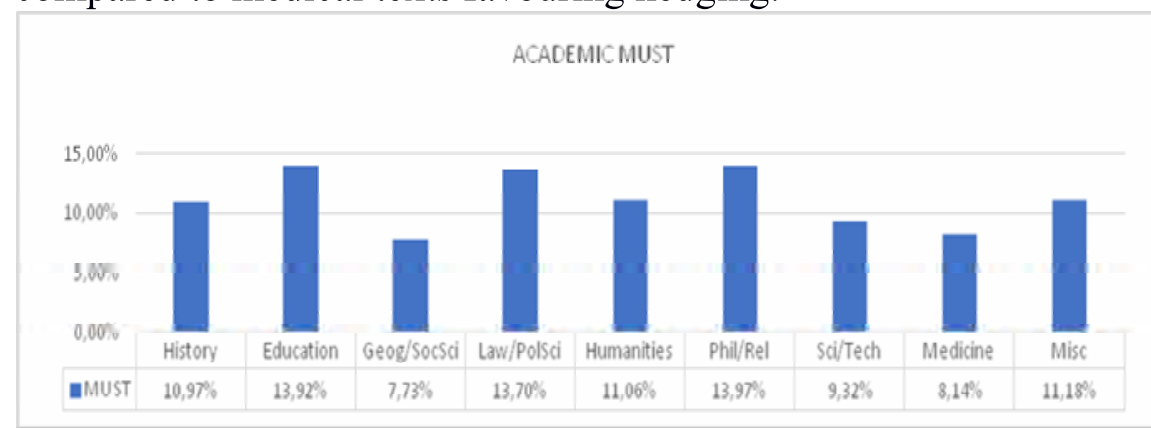

Figure 19. Frequency of MUST across the subsections of the Academic genre.

\section{Shall}

As Figure 20 indicates, Fiction genre (36.53\%), followed by the Academic genre (31.68\%), shows by far the highest frequency which is similar to the results for must. These genres are followed by Spoken (12.17\%) and Magazine (12.09\%) genres while the Newspaper genre has the lowest overall frequency $(7.52 \%)$. The total frequency of shall in COCA is the lowest out of all the central modal verbs with only $0.32 \%$.

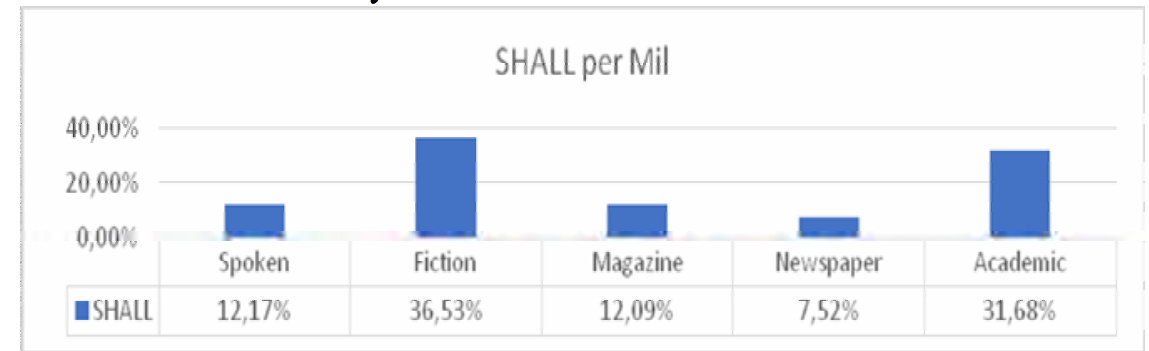

Figure 20. Normalized frequency of SHALL across genres. 
Once again, modal verbs such as shall, which are on the decline (Bowie et al., 2013), and are seen as more formal while also allowing for deontic interpretations, show high frequency in the Academic genre compared to the Spoken variety.

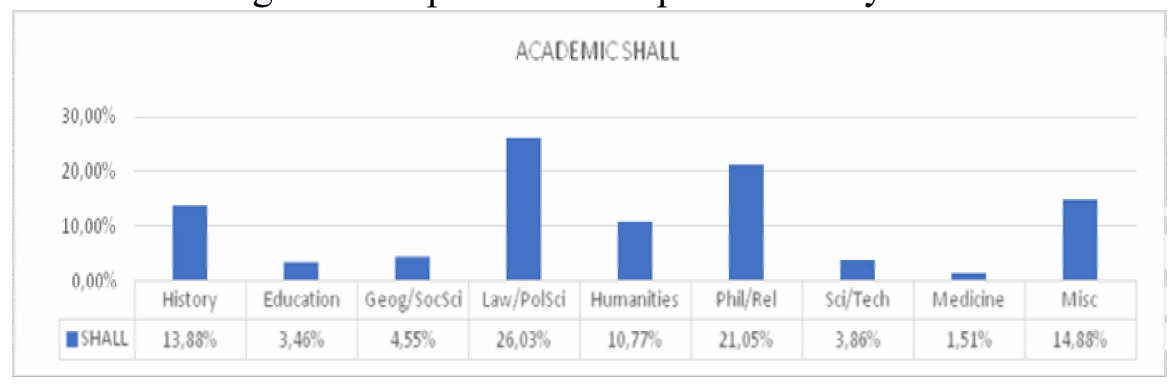

Figure 21. Frequency of SHALL across the subsections of the Academic genre.

An interesting point can be observed from Figure 21, as Law/PolSci and Phil/Rel subsections show the highest frequency with $26.03 \%$ and $21.05 \%$ each. Shall with its deontic interpretation is often used in legal texts (Coates \& Leech, 1980), and similar is expected for religious texts.

\section{Conclusion}

There is a clear lack of research on modal verbs across different genres, especially one including the spoken genre, as this genre is often neglected because of the time and money constraints involved in any sort of analysis of spoken data. Additionally, investigations into modal verbs from the theoretical standpoint of genre characteristics and influences are also limited. This led to the current corpus-based study which focuses on the genre differences across the two most diverse genres of the Corpus of Contemporary American English, Spoken and Academic genres. The analysis focused on the distribution of modal verbs across genres and subsections. The possible explanations behind the observed distribution patterns and frequency were also offered in terms of the democratization and colloquialization processes.

The results showed substantial and obvious differences in terms of distribution of individual modal verbs across genres. Specific modal verbs with particular set of characteristics 
corresponding to the genre traits showed higher frequencies in the corresponding genres compared to others. For example, modal verb may had the frequency of $37.93 \%$ in the Academic genre compared to the frequency of only $16.68 \%$ in the Spoken genre. Academic genre, a more formal genre, inclusive of deontic meanings of may and intended for specialized audience showed a higher frequency of the modal verb may, which is also often seen as formal, and allows for deontic interpretations. On the other hand, informal, open, spoken genre intended for general audience avoids employing face-threatening speech acts. Consequently, modal verb may showed the anticipated low frequency count. At the same time, modal verb must showed the lowest frequency of only $10.90 \%$ in this particular genre and, on the other hand, the Academic genre, being a more formal, written genre, showed almost the opposite results with respect to specific modal verbs. For example, modal verb will contained the lowest frequency $(11.18 \%)$ in this particular genre, while the highest frequency $(27.09 \%)$ was found in the Spoken genre $(24.80 \%)$. It seems likely that such a distribution is the result of the democratization process as less face threatening options are used within the Spoken genre: This once again suggests that genre can, indeed, indicate the distribution and modality types of modal verbs. Spoken genre also contained the highest frequency when it comes to modal verbs in total, while the opposite is true for the Academic genre which might be ascribed to the colloquialization process. Hence, the results of the present research prove the proposed hypothesis that Academic genre shows different frequency of use of the nine English central modal verbs compared to the spoken genre, and the noted differences may be ascribed to the different characteristics of the two genres. Furthermore, the observed lack of research on modal verbs across genres shows a promising area for further investigations into the relationship between modal verbs and genres in terms of modality types, which might have significant pedagogical implications, as suggested in a recent study conducted in the context of Bosnia and Herzegovina (Rizvić-Eminović, E., Bujak, A. Bureković, M. , 2017). It would be useful to investigate whether the modality types predominantly used in specific genres correspond to the predominantly used modal verbs. Similarly, investigations into other varieties of 
English would be beneficial as they could test the influence of the more dominant varieties (e.g. Americanization trend).

To conclude, the results clearly show that genre characteristics can be indicative of the frequency and distribution of modal verbs across various genres. The results also confirm previously observed differences between the noted frequency of modal verbs in corpora and in textbooks (Römer, 2004). A larger, comparative and corpus-based study across multiple genres with the focus solely on genre traits could further support the results and also offer further insight as to the available patterns of modal use. Such study, as well as any potential studies in the same field, could be especially useful in understanding an otherwise challenging area of English modal verbs and modality types.

\section{References}

Biber, D., Conrad, S., \& Reppen, R. (1998). Corpus Linguistics Investigating Language Structure and Use. New York: Cambridge University Press.

Biber, D., Johansson, S., Leech, G., Conrad, S., Finegan, E., \& Quirk, R. (1999). Longman grammar of spoken and written English. London: Longman.

Biber, D., \& Conrad, S. (2009). Register, genre, and style. Cambridge: Cambridge University Press.

Bowie, J., Wallis S., \& Aarts, B. (2013). Contemporary change in modal usage in spoken British English: mapping the impact of 'genre'. In: I., M. A., Carretero, M., Hita, J. A., \& Auwera, J. V. (eds.). (2013). English modality: core, periphery and evidentiality. Berlin; Boston: De Gruyter Mouton.

Coates, J. (1983). The semantics of the modal auxiliaries. London: Croom Helm.

Coates, J., \& Leech, G. (1980). The meanings of the modals in modern British and American English. York Papers in Linguistics 8, University of York, UK, 22-34.

Davies, M. (2009) The 385+ Million Word Corpus of Contemporary American English (1990-2008+): Design, Architecture, and Linguistic Insights. International 
Journal of Corpus Linguistics, 14, The Netherlans: John Benjamins Publishing Company.

Davies, M. (n.d.). COCA., from https://www.englishcorpora.org/cocal

Facchinetti, R. (2003). Pragmatic and sociological constraints on the functions of may in contemporary British English, in: R. Facchinetti, M. Krug \& F. Palmer (Eds.), Modality in Contemporary English (pp. 301-327). Berlin: Mouton de Gruyter.

Hinkel, E. (2009). The effects of essay topics on modal verb uses in L1 and L2 academic writing. Journal of Pragmatics, 41(4), 667-683.

Hyland, K. (1998). Hedging in Scientific Research Articles. Amsterdam: John Benjamins.

Krug, M. G. (2000). Emerging English modals: a corpus-based study of grammaticalization. Berlin: Mouton de Gruyter.

Leech, G. (2003). Modality on the move: the English modal auxiliaries 1961-1992. in R. Facchinetti, M. Krug \& F. Palmer (Eds.), Modality in Contemporary English (pp. 223-240). Berlin: Mouton de Gruyter.

Leech, G., Hundt, M., Mair, C., \& Smith, N. (2009). Change in Contemporary English: A Grammatical Study. Cambridge: University Press.

Mair, C., \& Leech, G. (2006). Current change in English syntax. In B. Aarts, \& A. MacMahon (Eds.), The Handbook of English Linguistics. (pp. 318-342). Oxford: Blackwell.

Millar, N. (2009). Modal verbs in TIME: Frequency changes 19232006. International Journal of Corpus Linguistics, 14(2), 191-220.

Mindt, D. (1995). An Empirical grammar of the English verb: modal verbs. Berlin: Cornelsen Verlag.

O'Keeffe, A., \& McCarthy, M. (eds.) (2010). The Routledge handbook of corpus linguistics. London: Routledge.

Rizvić-Eminović, E., Bujak, A. Bureković, M. . (2017). A Study of Trends in the Level of English Language Grammatical Competence at Zenica University. Third International Conference on Education, Culture and Identity, The Future of Humanities, Education and Creative Industries (pp. 197-206). Sarajevo: IUS. 
Römer, Ute. (2004). A corpus-driven approach to modal auxiliaries and their didactics. In: Sinclair, John McH. (ed.). How to Use Corpora in Language Teaching (pp 185-199). Amsterdam: John Benjamins.

Salkie, R., Busuttil, P., \& Auwera, J. V. (2009). Modality in English: theory and description. Berlin: De Gruyter. 


\title{
KORPUSNO ISTRAŽIVANJE RASPODJELE CENTRALNIH MODALNIH GLAGOLA U GOVORNOM I AKADEMSKOM ŽANRU COCA-E
}

Doc. dr. Edina Rizvić-Eminović

Đelaludina Šukalić, MA

\begin{abstract}
Sažetak
Ovo korpusno istraživanje se odnosi na devet centralnih modalnih glagola (can, could, will, would, may, might, shall, should, $i$ must) u dva odabrana žanra Korpusa savremenog američkog engleskog jezika (COCA): govornom i akademskom žanru, koji pokazuju najveći broj razlika po pitanju odlika žanra, poput formalnosti ili ciljane publike. Budući da su istraživanja o temi modalnih glagola u različitim žanrovima, naročito ona koja uključuju i govorni žanr, malobrojna, ovo istraživanje se bavi ovim dvama žanrovima kako bi se provjerila hipoteza prema kojoj uopćene odlike žanra utječu na odabir modalnih glagola. Kao rezultat, raspodjela modalnih glagola po različitim žanrovima se također razlikuje. Rezultati pokazuju da žanr zaista može biti pokazatelj raspodjele i učestalosti upotrebe modalnih glagola, što bi se moglo pripisati jezičkim procesima kolokvijalizacije i demokratizacije.
\end{abstract}

Ključne riječi: centralni modalni glagoli, govorni žanr, pisani žanr, korpusno istraživanje, raspodjela. 


$$
\text { د. أدينا ريزويتش - أمنوفيتش }
$$

م. جلالدينا شوكاليتش، كلية الفلسفة، جامعة زنيتسا

البحث اللغوي للأفعال المساعدة المشروطة في الأسلوب الشفاهي

والأكاديمي في مدونة اللغة الأمريكية والإبحليزية المعاصرة

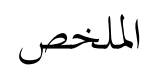

(can, could, يتناول هذا البحث اللغوي مدونة تسعة أفعال مساعدة مشروطة مركزية will, would, may, might, shall, should, i must) مدونة اللغة الإبخليزية الأمريكية المعاصرة : الأسلوبين الشفاهي والأكاديمي، (COCA) واللذين يظهران أكبر عدد من الاختلافات من حيث السمات النوعية مثل الشكلية أو الو

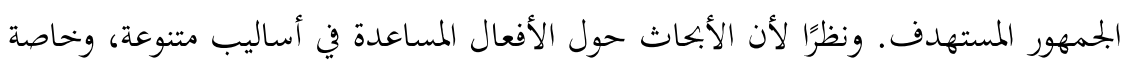

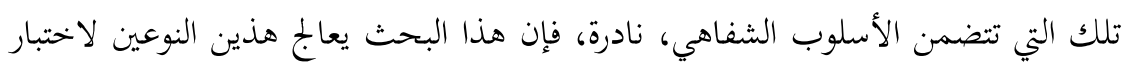

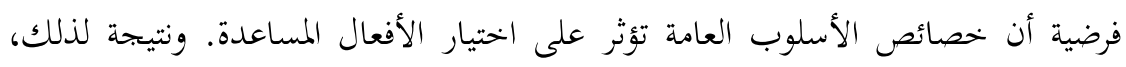

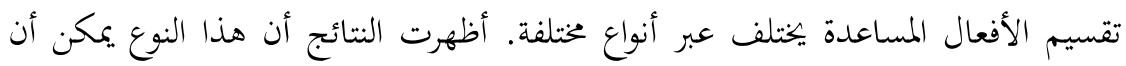

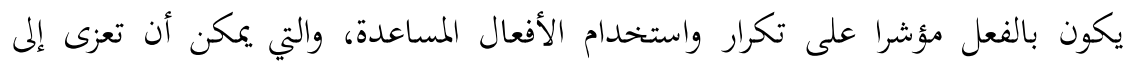
عمليات التدوين اللغوي وديمقراطيتها. الكلمات الأساسية: الأفعال المساعدة المشروطة، الأسلوب الشفاهي، المكتوب، الأسلوب-

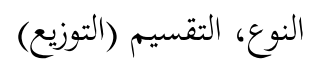

